\title{
GESTÃO URBANO-AMBIENTAL E NOVAS TERRITORIALIDADES
}

\author{
EDIVALDO FERNANDES RAMOS* \\ *Secretaria Municipal de Educação de Belo Horizonte; email: ediramos73@hotmail.com
}

O presente texto foi construído a partir da análise das contribuições de autores que se preocuparam com a investigação e entendimento da temática ambiental. Todos eles são de extrema importância, especificamente porque debatem questões centrais, como a política ambiental e sua implementação, os problemas relacionados à participação democrática e representação nos órgãos gestores, os conflitos de interesses presentes nesta discussão e a (in) eficácia na implementação da legislação ambiental.

No texto de Eder Jurandir Carneiro, que analisa o funcionamento do COPAM, órgão responsável pela regulação da política ambiental no estado de Minas Gerais, fica claro que este órgão tem sido o local de processamento de conflitos, que em sua maioria se resolvem na busca de consenso entre os atores envolvidos. Para Carneiro (2005) o Conselho sempre teve uma "vocação" ao "diálogo pedagógico", visto como processo de aprendizado do "entendimento" entre agentes "responsáveis", capaz de levar à formação de consensos negociados entre interesses divergentes.

De acordo com Carneiro ocorre neste órgão uma oligarquização da política ambiental, visto que a representatividade é limitada por uma pequena elite que possui o exercício do poder e que nele se perpetua. Desta forma os agentes que compõem o COPAM: ambientalistas, representantes do capital e membros da tecnoburocracia ambiental, apesar de estarem representando interesses divergentes, realizam na prática a compatibilização entre preservação ambiental e desenvolvimento, nos moldes do desenvolvimento sustentável. Para isso eles buscam excluir posicionamentos radicais que se oponham ao desenvolvimento. No final da história tende-se a ocorrer uma homogeneização dos discursos. Este esforço pela formação de consensos em interesses divergentes tem promovido a redução da política ambiental a um "jogo de mitigações". Para Carneiro (2005) à medida que o tempo passa, esses conflitos vão se tornando mais suaves, e o escopo de seu objeto vai se reduzindo até assumirem a forma de disputas "jurídicas" - geralmente cordiais e conduzidas de acordo com um conjunto de rotinas e procedimentos institucionalizados - acerca do grau de rigor com que se deve aplicar a norma ambiental pertinente para determinado caso de licenciamento ou infração ambiental.
No texto "Nascimento da APA Sul-RMBH: o poder da polêmica", a autora analisa os conflitos que se deram no processo de criação da APA Sul-RMBH, área na divisa de Belo Horizonte e Nova Lima, pertencente a empresas ligadas à mineração (Anglo Gold, MBR, Vale, dentre outras), vem sendo explorada com habitações na forma de condomínios. Esta é uma área de fundamental importância, principalmente no que se refere à questão da água, pois na APA SUL se encontram $70 \%$ do abastecimento de $\mathrm{BH}$ e $55 \%$ da RMBH. De acordo com Camargos (2004), a criação desta APA foi resultado da pressão de uma parcela de moradores, que mantinham forte vínculo urbano e possuíam renda compatível com as classes média e alta. Sobrepôs-se nesta área normas, leis e orientações políticas de setores e instâncias diferentes, incluindo instituições federais, estaduais e vários municípios, com suas respectivas visões sobre a gestão de recursos naturais. È importante ressaltar que os habitantes rurais, os moradores dos povoados e os empregados dos novos núcleos habitacionais não estavam concernidos no debate sobre a importância ambiental da região. Na maioria dos casos os moradores populares desconheciam residir em uma APA, ou mesmo o significado da palavra.

Camargos (2004) observa que os principais atores da criação da APA - Estado, associações ambientalistas e empresários compartilhavam lugares e, existiu mesmo uma "troca de cadeiras", apesar da aparente polarização do conflito. Proprietários de lotes na APA podem ser empresários do setor imobiliário e minerário, ou assumir funções no aparelho de Estado e vice-versa. Para a autora tal conflito não pode ser classificado como uma luta ambiental propriamente dita, visto que havia muitos interesses pessoais de associações de condomínios preocupados com "seu quintal". O discurso ambiental serviu de base a interesses de classe, e os órgãos gestores, dentre eles o COPAM, acabaram sendo "convencidos" da importância da criação da APA.

A ineficiência das políticas públicas na gestão urbana e a ineficácia da legislação ambiental e urbanística aparecem também em destaque nas análises de Martins (2006) e Carmo \& Tagnin (2001). Martins (2006) em seu estudo sobre a lei dos mananciais na região metropolitana de São Paulo, percebe que a existência da Lei de Proteção aos 
Mananciais não modificou o padrão de ocupação dessas áreas nem isolou os corpos d'água como era desejado. 0 aumento da pobreza, seguido do crescente déficit habitacional, a reduzida oferta de habitação de interesse social, a defasagem entre a condição econômica da população e o padrão legal estabelecido, o intrincado processo de licenciamento e a fragilidade da fiscalização fazem com que essa forma de ocupação do espaço irregular e precária - fosse a predominante na região.

Fica claro para o autor que a expansão periférica da cidade de São Paulo foi realizada sem a devida preocupação ambiental. Sendo que em muitos casos o poder público atuou como parceiro dos empreendedores, instalando infra-estrutura e investindo em propaganda. A legislação de proteção ambiental que deveria servir para conter tais empreendimentos acabou por favorecer alguns deles. Para Martins (2006) se por um lado a legislação de proteção ambiental restringe demasiadamente as possibilidades de uso e ocupação do solo, desvalorizando a terra localizada em áreas protegidas, por outro, não impede que essas áreas, uma vez agregando o valor "exclusividade", sejam super-valorizadas devido às características naturais e paisagísticas. Essas características permitem que os empreendedores supervalorizem seus empreendimentos, vendendo imóveis em locais afastados, por valores próximos aos do centro.

Carmo e Tagnin (2001) realizam a partir do estudo do Reservatório Billings, uma análise sobre os usos múltiplos da água e os diversos conflitos advindos destes usos. Eles identificam no estudo três usos, que não são os únicos, mas que para eles são os mais conflitantes: geração de energia, uso da água para a diluição de efluentes e o uso para abastecimento. As dificuldades para a efetivação do uso múltiplo, assim como a ocupação irregular na área do reservatório foram os problemas que caracterizaram o processo de realização de um Programa de Recuperação Ambiental da Bacia Billings. Este programa tinha como algumas de suas metas principais, o controle da ocupação das áreas da bacia, de desenvolvimento da qualidade ambiental e de redução e controle da poluição, além de criar instrumentos de sustentação econômico-social, de controle da formulação, implementação e eficácia do programa. A questão do uso múltiplo aparece como um problema para a área já que são muitos os seguimentos sociais e os interesses envolvidos nessa situação de escassez de água em uma região que continua se expandindo.

Novamente a questão da expansão periférica em áreas ambientalmente frágeis aparece e a ineficiência das políticas públicas na fiscalização e contenção da mesma também. Para os autores, além dos problemas citados, um outro entrave ao programa de recuperação da bacia de Billings foi a resistência de algumas secretarias (saneamento) e órgãos que viram neste projeto um dificultador para a atração de investimentos para a área, devido ao encarecimento da água.

Enfim, o que fica claro a partir das análises é que apesar da existência de uma legislação ambiental, a mesma não vem sendo cumprida, em função de falhas nos diversos órgãos de execução, e na concepção da própria legislação, que na maioria das vezes serve para reforçar o direito de propriedade ou não é adequada às condições reais do espaço. Os modelos de gestão ambiental apresentados têm sido pautados pelos padrões comportamentais de grupos e elites hegemônicas, desconsiderando os conflitos e contradições inerentes à problemática ambiental.

\section{Referências bibliográficas}

ANDERSON A.T., SWIHART G.H., ARTIOLI G., GEIGER C.A. 1984. Segregation vesicles, gas filter pressing, and igneous differentiation. Journal of Geology 92 (1): 55-72.

CARMO R.L., TAGNIN R. 2001. Uso Múltiplo da água e múltiplos conflitos em contextos urbanos: o caso do Reservatório Billings. In: Anais do IX Encontro Nacional da Anpur. Rio de Janeiro: ANPUR. 3, 1276-1286.

MARTINS M.L.R. 2006. Moradia e Mananciais: tensão e diálogo na metrópole. São Paulo: FAUUSP/FAPESP. Cap. 5, 56-66.

CAMARGOS R. Nascimento da APA SUL-RMBH: o poder da polêmica. In: Conflitos Ambientais no Brasil. Rio de Janeiro: Relume Dumará: Fundação Heinrich Böll. P. 131-146.

CARNEIRO E. J. 2005. A Oligarquização da "Política Ambiental" Mineira. In: A insustentável leveza da política ambiental. Belo Horizonte: Autêntica, 65-88. 